\title{
Juneau Icefield Mass Balance Program 1946-2011
}

\author{
M. Pelto ${ }^{1}$, J. Kavanaugh ${ }^{2}$, and C. McNeil ${ }^{3}$ \\ ${ }^{1}$ Department of Environmental Sciences, Nichols College, Dudley, MA 01571, USA \\ ${ }^{2}$ Department of Earth and Atmospheric Sciences, University of Alberta, Edmonton, AB T6G, Canada \\ ${ }^{3}$ US Geological Survey (USGS), 4210 University Dr., Anchorage, AK 99508-4626, USA
}

Correspondence to: M. Pelto (mspelto@ nichols.edu)

\begin{abstract}
Received: 30 March 2013 - Published in Earth Syst. Sci. Data Discuss.: 24 May 2013
Revised: 3 October 2013 - Accepted: 14 October 2013 - Published: 15 November 2013
\end{abstract}

\begin{abstract}
The annual surface mass balance records of the Lemon Creek Glacier and Taku Glacier observed by the Juneau Icefield Research Program are the longest continuous glacier annual mass balance data sets in North America. Annual surface mass balance $\left(B_{\mathrm{a}}\right)$ measured on Taku Glacier averaged $+0.40 \mathrm{~m} \mathrm{a}^{-1}$ from 1946-1985, and $-0.08 \mathrm{~m} \mathrm{a}^{-1}$ from 1986-2011. The recent annual mass balance decline has resulted in the cessation of the long-term thickening of the glacier. Mean $B_{\mathrm{a}}$ on Lemon Creek Glacier has declined from $-0.30 \mathrm{ma}^{-1}$ for the $1953-1985$ period to $-0.60 \mathrm{~m} \mathrm{a}^{-1}$ during the $1986-2011$ period. The cumulative change in annual surface mass balance is $-26.6 \mathrm{~m}$ water equivalent, a $29 \mathrm{~m}$ of ice thinning over the $55 \mathrm{yr}$. Snow-pit measurements spanning the accumulation zone, and probing transects above the transient snow line (TSL) on Taku Glacier, indicate a consistent surface mass balance gradient from year to year. Observations of the rate of TSL rise on Lemon Creek Glacier and Taku Glacier indicate a comparatively consistent migration rate of 3.8 to $4.1 \mathrm{~m} \mathrm{~d}^{-1}$. The relationship between TSL on Lemon Creek Glacier and Taku Glacier to other Juneau Icefield glaciers (Norris, Mendenhall, Herbert, and Eagle) is strong, with correlations exceeding 0.82 in all cases.
\end{abstract}

doi:10.5065/D6NZ85N3

\section{Introduction}

The Juneau Icefield Research Program (JIRP) is the longest ongoing program of its kind in North America, facilitating arctic and alpine education and expeditionary training in the fields of climate science, glaciology and glacial geology. JIRP has examined the surface mass balance of the Juneau Icefield since 1946, with principal efforts focused on Lemon Creek Glacier and Taku Glacier. This database is the longest direct measurement of surface mass balance in North America. The data are reported to the World Glacier Monitoring Service (WGMS) annually and made available through the Advanced Cooperative Arctic Data and Information Service (ACADIS). This paper reports on three data sets: (1) annual surface mass balance $\left(B_{\mathrm{a}}\right)$ record of the Taku and Lemon Creek glaciers, including their annually calculated equilibrium line altitude (ELA) and accumulation area ratio (AAR), as well as evaluation of validation and poten- tial errors; (2) probing transects above the transient snow line (TSL; snow line at time of observation) in 1984, 1998, 2004, 2005 and 2010; and (3) satellite image-determined transient snow line observations and rate of rise on Lemon Creek and Taku glaciers and TSL variations on six glaciers of the Juneau Icefield from 1995-2011 (Eagle, Herbert, Lemon Creek, Mendenhall, Norris and Taku). The Juneau Icefield straddles the Coast Range of southeast Alaska. The glaciers of the Juneau Icefield west of the crest experience an exceptionally maritime climate, with annual precipitation of around $3000-4000 \mathrm{~mm}$ water equivalent (w.e.) and an average annual temperature at the equilibrium line altitude (ELA) of $-1{ }^{\circ} \mathrm{C}$. Crucial to the survival of a glacier is its annual mass balance $\left(B_{\mathrm{a}}\right)$, i.e., the difference between accumulation and ablation (melting and sublimation) (Cogley et al., 2011). $B_{\text {a }}$ is the most sensitive climate indicator of a glacier. A glacier with a sustained negative annual mass balance is out of equilibrium and will tend to thin and retreat. A glacier with a 
sustained positive annual mass balance is out of equilibrium and will tend to thicken and advance. It is crucial that we continue to maintain the invaluable climate-glacier data set and provide it to the World Glacier Monitoring Service (WGMS).

\section{Field area}

\subsection{Taku Glacier}

Taku Glacier is a temperate, maritime valley glacier in the Coast Mountains of Alaska. With an area of $671 \mathrm{~km}^{2}$, it is the principal outlet glacier of the Juneau Icefield (Fig. 1). Taku Glacier can be divided into three zones with differing mass balance and flow characteristics. (1) The ablation zone, below the mean annual ELA of $925 \mathrm{~m}$ a.s.1. $\left(113 \mathrm{~km}^{2}\right)$, descends the trunk valley with no tributaries joining the glacier, with the single distributary tongue, Hole in the Wall, branching off from the main glacier $9 \mathrm{~km}$ above the terminus. (2) The lower firn zone, extending from the ELA at $925 \mathrm{~m}$ a.s.l. up to $1350 \mathrm{~m}$, is a zone where summer ablation is significant $\left(178 \mathrm{~km}^{2}\right)$. All of the main tributary glaciers (Southwest, Northwest, Matthes, and Demorest) join in this zone. (3) The upper firn zone extends from $1350 \mathrm{~m}$ a.s.l. to the head of the glacier at $2200 \mathrm{~m}$ a.s.l. $\left(380 \mathrm{~km}^{2}\right)$, comprising the principal accumulation region for each tributary except the Southwest Branch. Ablation is limited in this upper firn zone, with much of the summer meltwater refreezing within the firn, and limited sun cup development. This zone has a unique low backscatter signature in synthetic aperture radar (SAR) imagery (Ramage et al., 2000).

Taku Glacier attracts special attention because of its continuing, century-long advance (Pelto and Miller, 1990; Post and Motyka, 1995; Motyka and Echelmeyer, 2003), while all other outlet glaciers of the Juneau Icefield are retreating. Taku Glacier is also the thickest glacier yet measured in Alaska, $1477 \mathrm{~m}$ at an elevation of $800 \mathrm{~m}$ (Nolan et al., 1995). Taku Glacier is noteworthy for its positive annual mass balance from 1946-1988, which resulted from the cessation of calving around 1950 (Pelto and Miller, 1990). The positive mass balance resulting from this dynamic change with calving cessation gives the glacier an unusually high AAR (accumulation area ratio: percentage of glacier in accumulation zone at end of hydrologic year) for a non-calving glacier and makes the glacier relatively insensitive to climate change (Miller and Pelto, 1999; Pelto et al., 2008; Criscitiello, et al., 2010).

\subsection{Lemon Creek Glacier}

Lemon Creek Glacier, Alaska, was chosen as a representative glacier for the 1957/58 International Geophysical Year global glacier network. This choice was based on its sub-arctic latitude and on the ongoing mass balance program of JIRP that had begun in 1953 (Miller, 1972; Miller and Pelto, 1999). JIRP has continued annual surface mass balance measure-

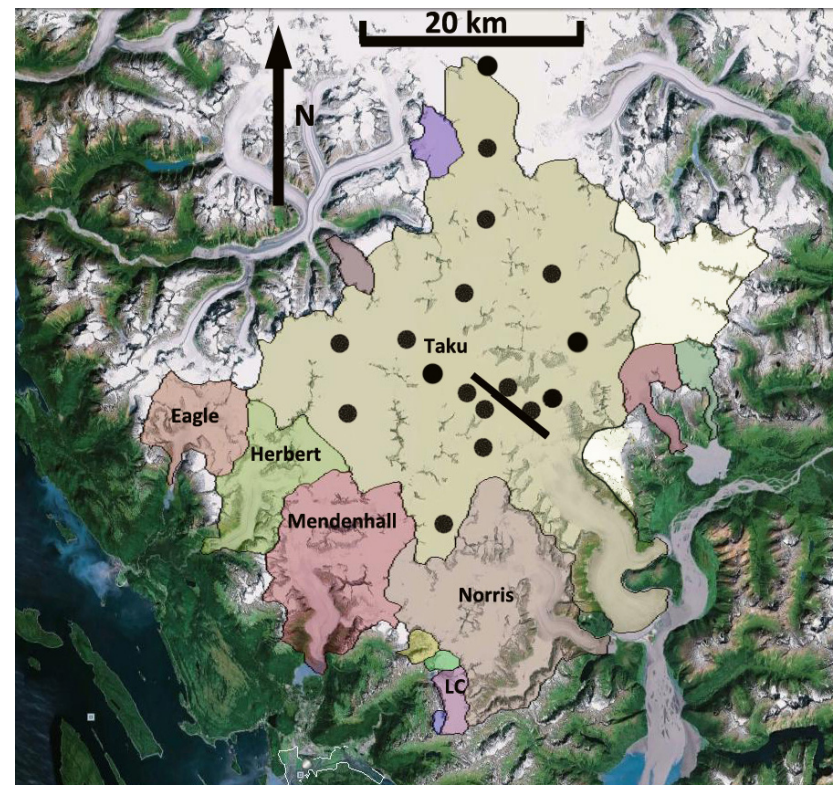

Figure 1. Base map of the Juneau Icefield, indicating the glaciers examined in this study. LC $=$ Lemon Creek Glacier, bold black line $=$ Probing transect on Taku Glacier. Black dots $=$ snow pit locations on Taku Glacier.

ments on Lemon Creek Glacier through the present (Fig. 2). In 1957 Lemon Creek Glacier was $6.4 \mathrm{~km}$ long and had an area of $12.67 \mathrm{~km}^{2}$ (Heusser and Marcus, 1964). In 1998 the glacier was $5.6 \mathrm{~km}$ long and had an area of $11.8 \mathrm{~km}^{2}$ (Marcus et al., 1995). From the head of the glacier at $1450 \mathrm{~m}$ a.s.l. to the mean ELA at 1050-1100 ma.s.l. the glacier flows northward; in the ablation zone the glacier turns westward, terminating at $750 \mathrm{~m}$ a.s.l. The glacier is divided into four sections: (1) steep peripheral northern and western margins draining into the main valley portion of the glacier; (2) a low slope $\left(4^{0}\right)$ upper accumulation zone from $1220 \mathrm{~m}$ a.s.l. to $1050 \mathrm{~m}$ a.s.l.; (3) a steeper section $\left(6^{0}\right)$ in the ablation zone as the glacier turns west from 1050-850 ma.s.l.; and (4) an icefall $\left(18^{0}\right)$ leading to the two fingered termini at $600 \mathrm{~m}$ a.s.l. This latter section was present up through 2005, but has now melted away and the terminus is at $750 \mathrm{~m}$ a.s.l. The maximum thickness exceeding $200 \mathrm{~m}$ is $1 \mathrm{~km}$ above the icefall (Miller, 1972). Lemon Creek Glacier has retreated $1200 \mathrm{~m}$ since 1948 and $800 \mathrm{~m}$ since 1957 , with an average of $10-13 \mathrm{~m} \mathrm{a}^{-1}$ between 1998 and 2009.

\section{Surface mass balance methods}

JIRP has relied on applying consistent mass balance methods at standard measurement sites (Pelto and Miller, 1990; Miller and Pelto, 1999; Pelto, 2011). The key annual measurements are as follows: (1) snow pits at fixed locations on Taku Glacier and Lemon Creek Glacier, ranging in elevation from $950 \mathrm{~m}$ to $1800 \mathrm{~m}$ a.s.l. (at each snow pit the water 


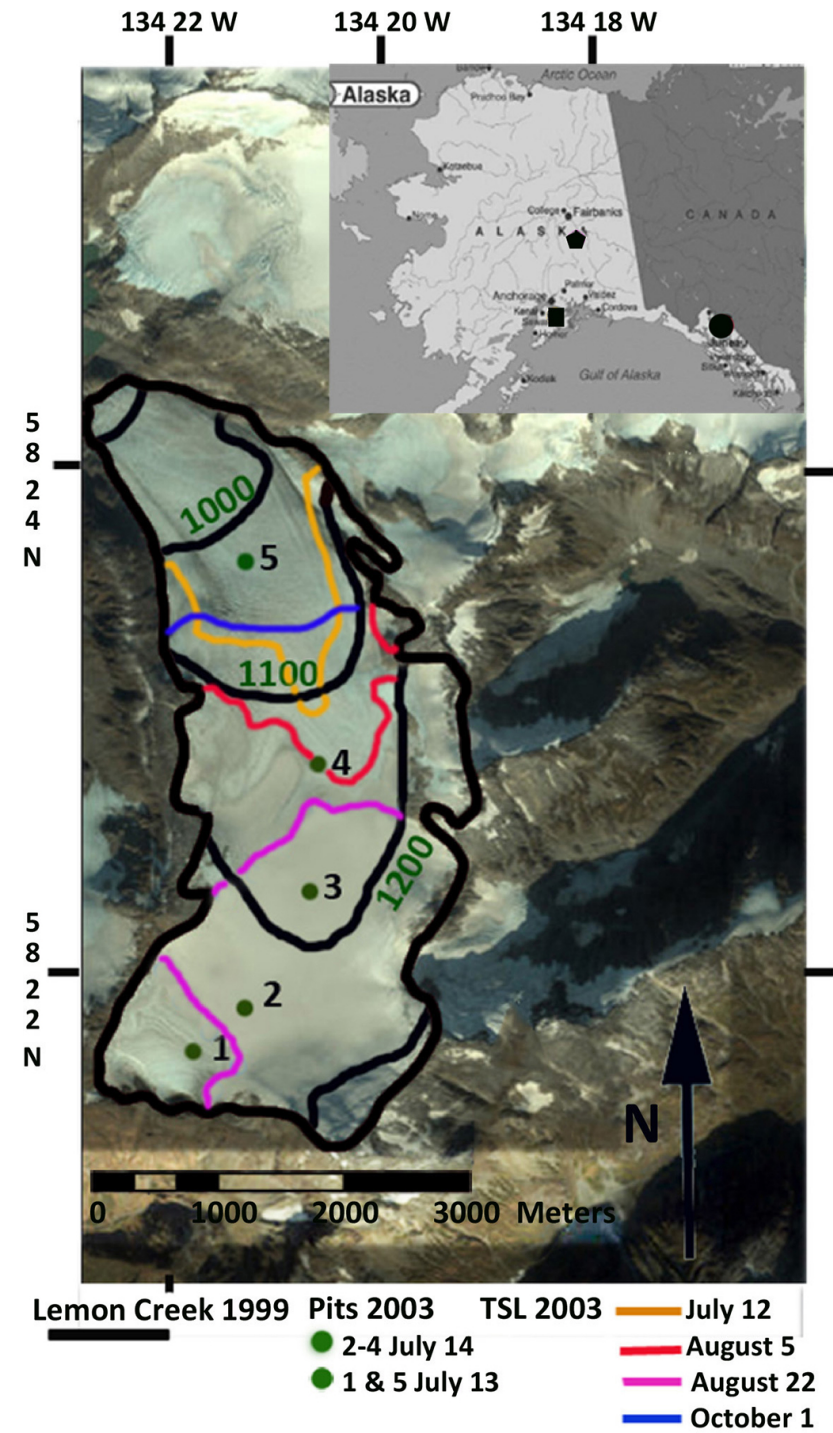

Figure 2. Map of Lemon Creek Glacier indicating primary snow pit locations, and the TSL location on specific dates in 2003. The black circle indicates the location of Lemon Creek Glacier, pentagon Gulkana Glacier and square Wolverine glacier.

equivalent (w.e.) is directly measured through the entire annual snow pack profile); (2) short-term ablation measurements at snow pits and along survey profiles with repeated height measurements of the stakes; and (3) observation of the TSL and ELA that allow ablation adjustments to snow pack.

\subsection{Snow pits}

The standard method used by JIRP to measure accumulation is the snow pit. Each snow pit is excavated down to the previous summer surface, identified by a dirty and/or ice horizon and density discontinuity. The most important aspect of the snow pit is accurate identification of the depth. The previous summer surface is well developed by the end of the ablation season on the Lemon Creek Glacier and below $1500 \mathrm{~m}$ a.s.l. on Taku Glacier (LaChapelle, 1954). Typically, a snow pit reaches the previous summer's surface, rather than blue ice, although it is not uncommon for a snow pit in the vicinity of the ELA to reach glacier ice. The previous summer's surface is a laterally continuous surface that typically has undergone several freeze/thaw cycles and often has a low density depth hoar just above it. In surface mass balance the unit of assessment is the snow water equivalent (SWE) of the snow pack. This is the mass per unit area of water that would be yielded were the snow pack melted, and is the product of snow depth and snow density. The density of the snow pack is quite variable during the winter and spring, but by July the mean density is generally consistent from year to year and location to location on the Juneau Icefield. LaChapelle (1954) noted remarkable uniformity of snow density in vertical profile and distribution over the glacier, and with time during the mid- to late summer. LaChapelle (1954) found the density of the snow pack to be consistently $540-565 \mathrm{~kg} \mathrm{~m}^{-3}$ after early July on the Taku Glacier; this has been observed by many other detailed studies since (Pelto and Miller, 1990). From 2003 to 2013, standard techniques have been used in density measurement through the depth profile of each snow pit; mean density has been $540 \mathrm{~kg} \mathrm{~m}^{-3}$, with a standard deviation of $30 \mathrm{~kg} \mathrm{~m}^{-3}$. Since there is no dry snow zone on the Lemon Creek or Taku glaciers, there is no difference in density with elevation. Ramage et al. (2000) found that surface wetness, grain size and density were all uniform across the icefield surface. Despite this fact, density is measured at each snow pit, in part because this is an excellent training tool.

Snow depth can be verified in shallow snow pack, those less than $3.5 \mathrm{~m}$, using probing or crevasse stratigraphy. Measurements of retained accumulation in a snow pit are completed during July and August, and are adjusted to end of the balance year values based on the variation of the TSL, observed ablation and surface mass balance profile (Pelto and Miller, 1990; Miller and Pelto, 1999).

For each of the 17 locations where snow pits are utilized on Taku Glacier and 5 locations on Lemon Creek Glacier, the snow pit is dug at a fixed location, verified using GPS. Once on site, the southern wall of the snow pit is marked off in order to prevent contaminating any density measurement that will be taken; the south wall of the snow pit is selected for density measurement in order to mitigate any error that may come from ablation caused by direct sunlight on the snow pit wall. A snow pit is always dug at least $50 \mathrm{~cm}$ into the previous year's firn in order to ensure continuity of the layer. Once the snow pit is dug down into the previous year's layer, the southern wall of the snow pit is shaved back to expose a flat, clean face from the top of the snow pit down into the previous year's layer; this face is used to take density measurements of the snow pack. Using a $500 \mathrm{cc}$ snow corer, samples are taken horizontally every ten centimeters down the vertical profile of the snow pit into the previous year's layer and the 


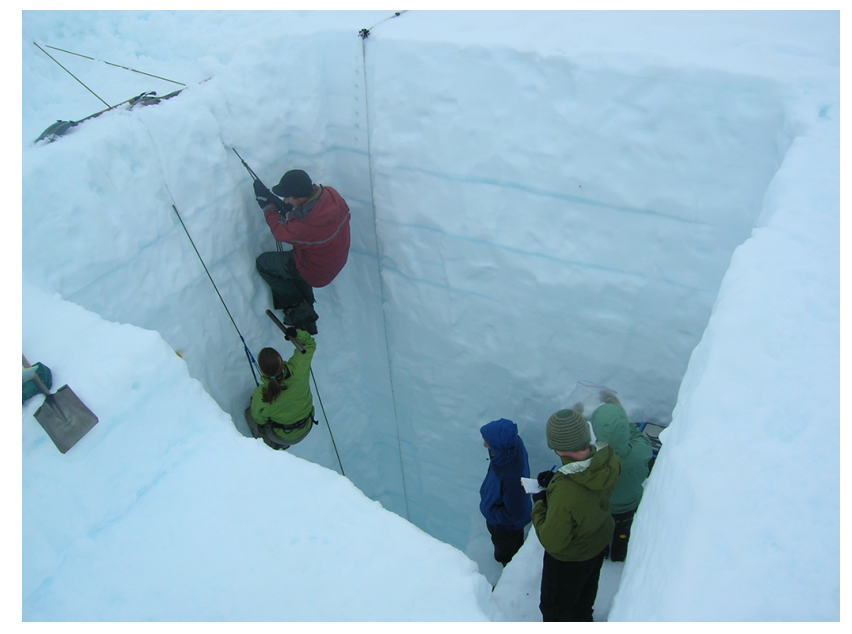

Figure 3. Snow pit location on Taku Glacier in 2011. Note the ice lenses. Density measurements are being taken from the south wall; the tape measure aids recording ice lens and sample depths.

density measured. The final step of the snow pit observations is to record all ice lenses present in the vertical profile of the snow pack (Fig. 3). An ice lens is a horizontal layer of ice formed when water percolates through the snow pack, hits a denser and/or colder layer of snow, spreads out laterally, and refreezes. The depth, thickness, and continuity of all ice lenses are recorded. Due to the small size of these features, the density of the lens is assumed at $900 \mathrm{~kg} \mathrm{~m}^{-3}$.

Due to the presence of ice within the snow pack, we report water equivalent depths rather than snow water equivalent depths. The w.e. for each snow pit is calculated using measurement of snow depth, snow density, total thickness of ice lenses within the snow pack, and an assumed density of ice.

w.e. $=d_{\mathrm{s}} \overline{\rho_{\mathrm{s}}}+d_{\mathrm{i}} \overline{\rho_{\mathrm{i}}}$

Where $d_{\mathrm{s}}$ is the depth of snow minus the sum thickness of all ice lenses, multiplied by $\overline{\rho_{\mathrm{s}}}$ the mean column density of snow sampled horizontally in $10 \mathrm{~cm}$ intervals unless ice is present. Water equivalent ice lenses present in snow pack is accounted with $d_{\mathrm{i}}$ as the sum thickness of all ice lenses present along vertical profile of snow pack, multiplied by $\overline{\rho_{\mathrm{i}}}$ an assumed ice density of $900 \mathrm{~kg} \mathrm{~m}^{-3}$. The sum of snow water equivalent and ice water equivalent quantifies the water equivalent for each snow pit location.

On Taku Glacier, six of the snow pit sites are near the ELA ranging from $950-1200 \mathrm{~m}$ a.s.l., six are located at 1200 $1400 \mathrm{~m}$ a.s.l. and five are located at $1400-1800 \mathrm{~m}$ a.s.l. altitude. Compared with Gulkana Glacier $\left(19 \mathrm{~km}^{2}\right)$ and Wolverine Glacier $\left(18 \mathrm{~km}^{2}\right)$, where the USGS annually assesses glacier mass balance from 3 to 4 measurement sites, the number of measurements on Taku Glacier is large (March and Trabant, 1996; Mayo et al., 2004). However, because the size of the Taku Glacier is more than an order of magnitude larger than either Gulkana or Wolverine glaciers, the measurement density is still lower than at the Alaskan benchmark glaciers. Furthermore, the distribution of annual measurements on Taku Glacier is skewed toward the ELA, and is nonexistent in the ablation zone. On Gulkana Glacier there is one site in the ablation zone, two sites near the ELA, and no sites in the upper $600 \mathrm{~m}$ of the glacier (March and Trabant, 1996). On Wolverine Glacier there is one site in the ablation zone, one site at the ELA and one site in the accumulation zone (Mayo et al., 2004). Van Beusekom et al. (2010) noted that the result on Wolverine Glacier was that the annual surface mass balance record differed from the geodetic record, leading to an adjustment to the long-term $B_{\mathrm{a}}$ record using a degree day based mass balance model. Because of these differences, extrapolations of mass balance from observations sites are commonly made, and represent a consistent source of error in Alaskan glacier mass balance assessments (Miller and Pelto, 1999). The advantage on Taku Glacier is that there are multiple measurement sites at each elevation, and in each tributary, which provides a more robust basis for annual mass balance gradient; the disadvantage is that the areal extent over which the extrapolations are made is larger. Current work using high frequency ground penetrating radar to precisely assess the annual mass balance retained snow depth in more detail is in progress.

\subsection{Ablation assessment}

Ablation is also observed annually during the field season, at snow pit locations, survey stakes located along survey lines where repeat surveys are completed, and through satellite observations of the migration of the TSL since 1998 (Pelto and Miller, 1990; Pelto et al., 2008). These ablation stakes, driven into the snow in the accumulation zone record the ablation of the remaining snow pack in the accumulation zone, between the time of snow pit measurements in July and the end of the ablation season in early September. This provides an essential measure for adjusting the July accumulation thickness snow pit measurements to the end of the ablation season. On Lemon Creek Glacier, the maximum number of such ablation stakes used during a single season was 200 in 1967. During the several years where more than 30 ablation stakes were emplaced, it is apparent that the ablation rate above 900 m a.s.l. is nearly constant on the Lemon Creek Glacier, whereas below $900 \mathrm{~m}$ a.s.l. the ablation rate increases with decreasing surface elevation.

On Lemon Creek Glacier from 1998-2011 the average ablation observed over a 162 day period was $0.031 \mathrm{~m} \mathrm{~d}^{-1}$. The maximum ablation observed over a period of at least 4 consecutive days was $0.039 \mathrm{~m} \mathrm{~d}^{-1}$ in 2005 and the minimum was $0.029 \mathrm{~m} \mathrm{~d}^{-1}$ in 2006. On Taku Glacier at $1120 \mathrm{~m}$ for the 1998-2011 period, average ablation over a span of 127 days was $0.027 \mathrm{~m} \mathrm{~d}^{-1}$. Ablation for at least 4 consecutive days ranged from a high of $0.033 \mathrm{~m} \mathrm{~d}^{-1}$ in 2005 to a low of $0.022 \mathrm{~m} \mathrm{~d}^{-1}$ in 1999 . 
On Taku Glacier in the ablation zone, the mass balance profile is adjusted based on the ELA, on measurements of ablation in nine different years from 1950 to 1997, including annual ablation measurements on cross survey profiles since 1998. The resulting ablation is a maximum at the terminus, at $12 \mathrm{~m} \mathrm{a}^{-1}$ (Pelto and Miller, 1990). Independent examination of ablation at the terminus (Motyka and Echelmeyer, 2003) has identified ablation rates at the terminus of $12-14 \mathrm{~m} \mathrm{a}^{-1}$ during two slightly warmer than usual ablation seasons 2003 and 2004. Boyce et al. (2007) noted ablation on neighboring Mendenhall Glacier at elevations from 0-300 $\mathrm{m}$ a.s.l. ranged from 10 to $14 \mathrm{~m}$ in 1998, 2000, 2003, 2004 and 2005.

\subsection{Probing and crevasse stratigraphy}

The snow pit is a point measurement of w.e. amidst the vast expanse of the icefield. To address the representativeness of snow pits and the associated error resulting from extrapolating from snow pits; in 1984, 1998, 2004, 2005 and 2010, JIRP measured the mass balance at an additional 100-500 points in the accumulation area with probing transects that extend outward from snow pits, to better determine the distribution of accumulation around a snow pit location. Measurements were taken along profiles at 100-250 $\mathrm{m}$ intervals. At each measurement point three depth measurements were made $25 \mathrm{~m}$ apart. The standard deviation for measurements sites within $25 \mathrm{~m}$ of each other was $7 \mathrm{~mm}$, and $17 \mathrm{~mm}$ for sites within $100 \mathrm{~m}$ of each other; this indicates the consistency of mass balance near snow pit sites.

Retained accumulation thickness has been observed at up to 300 points in a single summer season on Lemon Creek Glacier (1998) and 450 measurements on Taku Glacier (1998). Probing is not effective at depths greater than $5 \mathrm{~m}$. The probe used is a $3 / 4$ inch steel probe that easily penetrates ice lenses within the snow pack because the ice layers have comparatively soft unconsolidated snow beneath them. The previous summer surface cannot be penetrated because the entire layer was melted and refrozen many times, raising its density and cohesion.

Annual layers in the walls of crevasses are often quite obvious, similar to reading tree ring width for climate analysis. Crevasse stratigraphy provides a means to view the two dimensional nature of the annual layer, in contrast to a point measurement yielded by probing or the small scale view provided by a snow pit. Only vertically walled crevasses can be used for these observations. The key to identification of the annual layer in crevasses is the lateral continuity of the ice layer, as no other feature will be continuous. Crevasse stratigraphy is not a standard method used on the Taku Glacier, but has been used since the beginning of the program for validating snow pit snow depth observations in specific regions of the glacier where snow depths are large and probing cannot be used for validation.

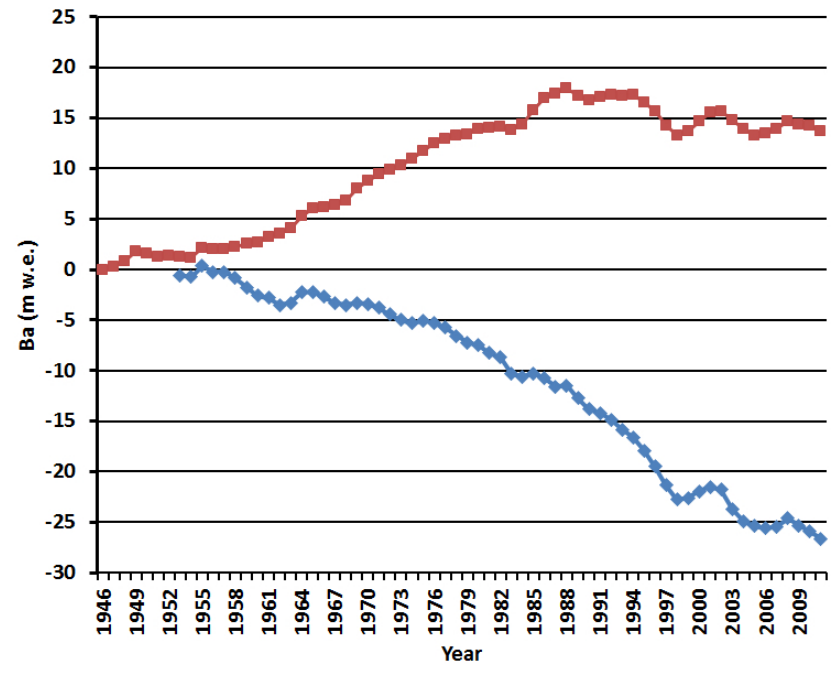

Figure 4. Cumulative annual surface mass balance record of Taku Glacier (red) and Lemon Creek Glacier (blue).

\section{Results}

\subsection{Annual surface mass balance record}

On Taku Glacier, the annual ELA has risen $60 \mathrm{~m}$ from the 1946-1985 period to the $1986-2010$ period. Mean $B_{\mathrm{a}}$ during the two periods were +0.40 and $-0.08 \mathrm{~m}$ w.e. $\mathrm{a}^{-1}$, respectively, indicative of the snow line rise resulting in cessation of the long-term thickening of the glacier (Table 1). This cumulative change in $B_{\mathrm{a}}$ from $1946-2011$ is $+13.7 \mathrm{~m}$ w.e. (Fig. 4). The long-term positive $B_{\mathrm{a}}$ mass balance is continuing to drive glacier advance (Pelto and Miller, 1990; Post and Motyka, 1995; Pelto et al., 2008). All other outlet glaciers of the Juneau Icefield are retreating, and are thus consistent with the dominantly negative alpine glacier mass balance that has been observed globally (Zemp et al., 2009).

Mean $B_{\mathrm{a}}$ on Lemon Creek Glacier has declined from $-0.3 \mathrm{~m}$ w.e. $\mathrm{a}^{-1}$ for the $1953-1985$ period to $-0.60 \mathrm{~m}$ w.e. $\mathrm{a}^{-1}$ during the $1986-2011$ period. The cumulative change $B_{\mathrm{a}}$ is $-26.6 \mathrm{~m}$, a $29 \mathrm{~m}$ ice thickness loss over the $55 \mathrm{yr}$ (Table 1 ).

\subsection{Mass balance record validation}

Possible errors in the mass balance record include the sparse nature of measurement points $\left(1\right.$ per $\left.37 \mathrm{~km}^{2}\right)$ on Taku Glacier, extrapolation to the end of the mass balance year from snow pit measurements in July or early August, infrequent measurements in the ablation zone, and measurements carried out by many different investigators. However, Pelto and Miller (1990) suggest that these sources of error are mitigated by (1) measuring the same locations at the same time using the same methods each year; (2) using a mass balance profile from nine years of ablation data to extrapolate mass balance in the ablation zone; and (3) validation of snow depth variation using probing transects (see next 
Table 1. Mass balance record of the Taku and Lemon Creek glaciers, including annual mass balance ( $\left.B_{\mathrm{a}}\right)$, ELA, AAR and cumulative $B_{\mathrm{a}}$.

\begin{tabular}{|c|c|c|c|c|c|c|c|c|}
\hline Year & $\begin{array}{r}\text { Taku Ba } \\
\text { (mm w.e.) }\end{array}$ & $\begin{array}{r}\text { LC Ba } \\
\text { (mm w.e.) }\end{array}$ & $\begin{array}{r}\text { LC cumulative } B_{\mathrm{a}} \\
\text { (mm w.e.) }\end{array}$ & $\begin{array}{r}\text { Taku cumulative } B_{\text {a }} \\
\text { (mm w.e.) }\end{array}$ & $\begin{array}{r}\text { Taku ELA } \\
(\mathrm{m})\end{array}$ & $\begin{array}{r}\text { LC ELA } \\
(\mathrm{m})\end{array}$ & LC AAR & Taku AAR \\
\hline 1946 & -40 & & & -40 & 980 & & & 85 \\
\hline 1947 & 360 & & & 320 & 900 & & & 88 \\
\hline 1948 & 510 & & & 830 & 870 & & & 89 \\
\hline 1949 & 930 & & & 1760 & 800 & & & 90 \\
\hline 1950 & -180 & & & 1580 & 1010 & & & 84 \\
\hline 1951 & -340 & & & 1240 & 1160 & & & 68 \\
\hline 1952 & 160 & & & 1400 & 950 & & & 86 \\
\hline 1953 & -150 & -560 & -560 & 1250 & 1010 & 1080 & 40 & 84 \\
\hline 1954 & -70 & -180 & -740 & 1180 & 1160 & 1025 & 58 & 68 \\
\hline 1955 & 970 & 1120 & 380 & 2150 & 950 & 810 & 90 & 86 \\
\hline 1956 & -130 & -640 & -260 & 2020 & 1010 & 1075 & 40 & 84 \\
\hline 1957 & -40 & 0 & -260 & 1980 & 980 & 1000 & 62 & 85 \\
\hline 1958 & 210 & -580 & -840 & 2190 & 780 & 1040 & 52 & 91 \\
\hline 1959 & 350 & -900 & -1740 & 2540 & 1000 & 1150 & 33 & 84 \\
\hline 1960 & 160 & -820 & -2560 & 2700 & 1010 & 1130 & 35 & 84 \\
\hline 1961 & 480 & -240 & -2800 & 3180 & 930 & 1080 & 40 & 87 \\
\hline 1962 & 390 & -690 & -3490 & 3570 & 915 & 1110 & 37 & 88 \\
\hline 1963 & 570 & 170 & -3320 & 4140 & 950 & 970 & 66 & 86 \\
\hline 1964 & 1130 & 1040 & -2280 & 5270 & 885 & 885 & 80 & 90 \\
\hline 1965 & 790 & 80 & -2200 & 6060 & 900 & 980 & 65 & 90 \\
\hline 1966 & 80 & -490 & -2690 & 6140 & 875 & 1100 & 38 & 89 \\
\hline 1967 & 250 & -600 & -3290 & 6390 & 750 & 1130 & 36 & 91 \\
\hline 1968 & 460 & -220 & -3510 & 6850 & 810 & 1060 & 58 & 90 \\
\hline 1969 & 1170 & 210 & -3300 & 8020 & 965 & 1000 & 63 & 86 \\
\hline 1970 & 760 & -90 & -3390 & 8780 & 930 & 1060 & 58 & 91 \\
\hline 1971 & 630 & -400 & -3790 & 9410 & 885 & 1110 & 39 & 88 \\
\hline 1972 & 420 & -650 & -4440 & 9830 & 730 & 1140 & 34 & 92 \\
\hline 1973 & 520 & -520 & -4960 & 10350 & 825 & 1110 & 39 & 90 \\
\hline 1974 & 580 & -370 & -5330 & 10930 & 850 & 1090 & 42 & 89 \\
\hline 1975 & 850 & 290 & -5040 & 11780 & 800 & 1010 & 63 & 90 \\
\hline 1976 & 660 & -250 & -5290 & 12440 & 850 & 1080 & 48 & 89 \\
\hline 1977 & 470 & -480 & -5770 & 12910 & 885 & 1110 & 40 & 88 \\
\hline 1978 & 310 & -800 & -6570 & 13220 & 915 & 1150 & 35 & 87 \\
\hline 1979 & 140 & -630 & -7200 & 13360 & 950 & 1110 & 40 & 86 \\
\hline 1980 & 540 & -270 & -7470 & 13900 & 870 & 1100 & 42 & 89 \\
\hline 1981 & 120 & -810 & -8280 & 14020 & 980 & 1120 & 40 & 85 \\
\hline 1982 & 150 & -430 & -8710 & 14170 & 950 & 1070 & 51 & 86 \\
\hline 1983 & -420 & -1620 & -10330 & 13750 & 1085 & 1220 & 17 & 79 \\
\hline 1984 & 640 & -250 & -10580 & 14390 & 875 & 1010 & 65 & 89 \\
\hline 1985 & 1400 & 330 & -10250 & 15790 & 600 & 965 & 75 & 93 \\
\hline 1986 & 1200 & -510 & -10760 & 16990 & 720 & 1070 & 51 & 92 \\
\hline 1987 & 390 & -840 & -11600 & 17380 & 910 & 1100 & 43 & 88 \\
\hline 1988 & 600 & 110 & -11490 & 17980 & 890 & 1000 & 69 & 88 \\
\hline 1989 & -810 & -1240 & -12730 & 17170 & 1115 & 1130 & 40 & 74 \\
\hline 1990 & -450 & -1110 & -13840 & 16720 & 1080 & 1125 & 42 & 79 \\
\hline 1991 & 380 & -380 & -14220 & 17100 & 900 & 1050 & 60 & 88 \\
\hline 1992 & 170 & -660 & -14880 & 17270 & 940 & 1075 & 54 & 86 \\
\hline 1993 & -40 & -980 & -15860 & 17230 & 980 & 1130 & 43 & 85 \\
\hline 1994 & 90 & -760 & -16620 & 17320 & 970 & 1100 & 46 & 85 \\
\hline 1995 & -760 & -1310 & -17930 & 16560 & 1050 & 1150 & 38 & 81 \\
\hline 1996 & -960 & -1580 & -19510 & 15600 & 1150 & 1370 & 5 & 68 \\
\hline 1997 & -1340 & -1810 & -21320 & 14260 & 1225 & 1400 & 5 & 60 \\
\hline 1998 & -980 & -1460 & -22780 & 13280 & 1120 & 1300 & 7 & 73 \\
\hline 1999 & 400 & 200 & -22580 & 13680 & 900 & 1020 & 68 & 88 \\
\hline 2000 & 1030 & 650 & -21930 & 14710 & 750 & 900 & 82 & 91 \\
\hline 2001 & 880 & 400 & -21530 & 15590 & 850 & 950 & 77 & 89 \\
\hline 2002 & 100 & -250 & -21780 & 15690 & 975 & 1025 & 67 & 88 \\
\hline 2003 & -900 & -1900 & -23680 & 14790 & 1100 & 1400 & 5 & 77 \\
\hline 2004 & -830 & -1250 & -24930 & 13960 & 1100 & 1150 & 59 & 86 \\
\hline 2005 & -720 & -470 & -25400 & 13240 & 1050 & 1050 & 61 & 86 \\
\hline 2006 & 230 & -170 & -25570 & 13470 & 975 & 1025 & 68 & 86 \\
\hline 2007 & 480 & 150 & -25420 & 13950 & 930 & 1000 & 72 & 87 \\
\hline 2008 & 750 & 800 & -24620 & 14700 & 800 & 920 & 80 & 90 \\
\hline 2009 & -310 & -700 & -25320 & 14390 & 960 & 1060 & 51 & 86 \\
\hline 2010 & -120 & -580 & -25900 & 14270 & 1000 & 1075 & 55 & 83 \\
\hline 2011 & -550 & -720 & -26620 & 13720 & 1025 & 1100 & 47 & 82 \\
\hline
\end{tabular}


section). The principal error is due to the lack of data from the ablation zone. The mass balance profile for the glacier in the ablation zone is based solely on ablation measurements. These data indicate a consistent gradient in the ablation zone. The profile is adjusted to zero at the observed ELA. Annual observations of ablation are not a standard method because of costs and logistics; this does add uncertainty in the mass balance assessment. The mass balance gradient in the ablation zone published by Miller and Pelto (1990) for Taku Glacier has been verified by independent work by Motyka and Echelmeyer (2003) on Taku Glacier and on neighboring Mendenhall Glacier (Boyce et al., 2007).

The Taku Glacier annual surface mass balance record has been validated with geodetic balances from independent observation of glacier surface elevation change, using the ongoing laser altimetry by the University of Alaska, Fairbanks (Sapiano et al., 1998; Arendt et al., 2002; Larsen et al., 2007). This was accomplished from a centerline profile providing a mean glacier surface elevation change. Surface elevation change is not strictly a measure of mass balance, though it is reported as such (Arendt, 2006). Surface dynamics can also play a role. On Taku Glacier in the vicinity of the ELA, annual velocity surveys indicate consistent ice dynamics from 1950 to 2006, indicating that surface elevation change should mostly reflect surface mass balance (Pelto et al., 2008). The observed change in Taku Glacier surface elevation was $+0.69 \mathrm{~m} \mathrm{a}^{-1}$ from 1948 to 1993 and $-0.28 \mathrm{~m} \mathrm{a}^{-1}$ from 1993 to 1997 (Arendt, 2006). The observed mean $B_{\mathrm{a}}$ for these periods from field observations is $+0.38 \mathrm{~m} \mathrm{a}^{-1}$ for $1948-1993$ and $-0.60 \mathrm{~m} \mathrm{a}^{-1}$ for $1993-1997$. The direct measurement record includes the large negative mass balance of 1997, while the laser altimetry only includes part of the 1997 ablation season and would tend to underestimate thinning by a small amount (Sapiano et al., 1998). Repeat laser altimetry profiling indicates a $B_{\mathrm{a}}$ of $-0.21 \mathrm{~m} \mathrm{a}^{-1}$ for the $1993-$ 2007 period, compared to the JIRP mean $B_{\mathrm{a}}$ of $-0.16 \mathrm{~m} \mathrm{a}^{-1}$. Comparisons of surface elevations from the 2000 Shuttle Radar Topography Mission and a DEM derived from the 1948 USGS mapping indicate a mean $B_{\mathrm{a}}$ of $+0.45 \mathrm{~m} \mathrm{a}^{-1}$ versus the JIRP record of $+0.27 \mathrm{~m} \mathrm{a}^{-1}$ for the 1948-2000 period (Larsen et al., 2007). The long-term observed ice surface elevation changes taken over varied periods using different techniques validates the accuracy of the annual surface mass balance record of the Taku Glacier.

On Lemon Creek Glacier the annual surface mass balance record determined from field measurement yields a cumulative mass balance of $-26.6 \mathrm{~m}$ w.e. from 1953 to 2011 . The cumulative $B_{\mathrm{a}}$ record of $-12.7 \mathrm{~m}$ w.e. ( $13.9 \mathrm{~m}$ of ice thickness) from 1957 to 1989 compares well to the thinning identified from geodetic methods of 1957-1989 of -13.2 (Marcus et al., 1995). The cumulative $B_{\mathrm{a}}$ record of $-17.1 \mathrm{~m}$ w.e. $(-19.0 \mathrm{~m}$ of ice thickness) from the period 1957-1995 compares favorably to an observed ice thickness of $-16.4 \mathrm{~m}$ (Sapiano et al., 1998). Airborne surface profiling by the University of Alaska - Fairbanks (Sapiano et al., 1998; Larsen

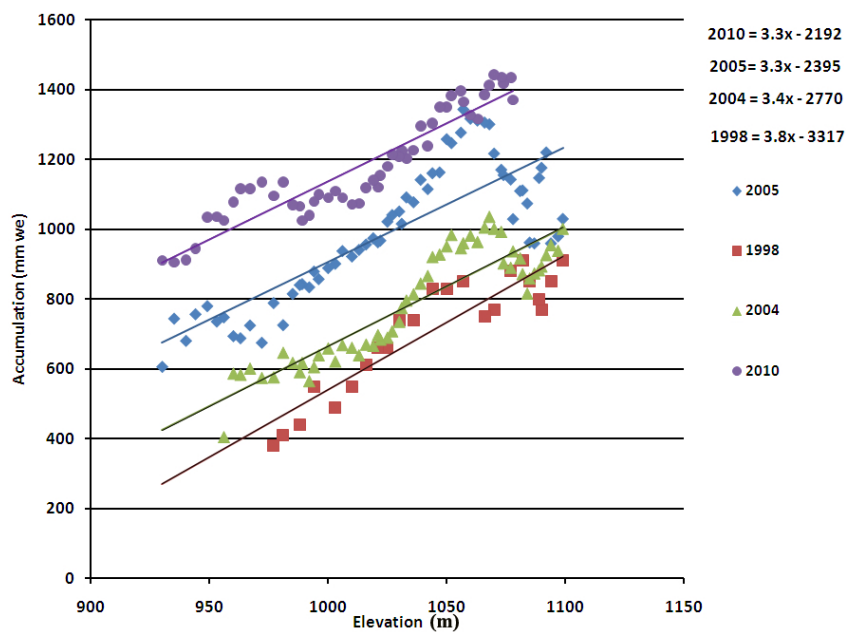

Figure 5. Taku Glacier mass balance profile determined from probing in various years. Note the similar gradient in this elevation range of the Taku Glacier in July near the ELA.

et al., 2007) noted an additional $-12.9 \mathrm{~m}$ surface elevation change, equivalent to a cumulative annual mass balance of $-11.5 \mathrm{~m}$ w.e. compared to annual surface mass balance of $-9.7 \mathrm{~m}$ w.e. from 1994-2007. The error in both geodetic programs is less than $1.5 \mathrm{~m}$. In each of the three time intervals using two different ice surface elevation change assessment techniques, the $B_{\mathrm{a}}$ record is confirmed. Future work addressing the minor discrepancies between the geodetic and direct measurement records is currently being reviewed.

\section{Probing transects for determination of balance gradient}

Mauri Pelto in late July of 1984, 1998; Matt Beedle in late July of 2004, 2005; and Chris McNeil in late July of 2010, 2011 measured the mass balance along a transect from near the TSL at 900 to $1150 \mathrm{~m}$ on Taku Glacier by probing at a horizontal interval of $200 \mathrm{~m}$. This method allows direct identification of the mass balance gradient at this elevation (Table 2). The mass balance gradient is determined using data from an elevation of 925 to 1100 m a.s.l., as this is the interval with consistent data each year.

The mass balance gradient determined from probing between 925 and $1100 \mathrm{~m}$ a.s.l. ranges from 3.3 to $3.8 \mathrm{~mm} \mathrm{~m}^{-1}$, with a mean of $3.5 \mathrm{~mm} \mathrm{~m}^{-1}$. The mass balance gradient has been consistent on Taku Glacier for each year observed regardless of the respective mass balance (Fig. 5). Standard deviation of accumulation along this transect from the best fit linear regression is $40 \mathrm{~mm}$. The mass balance gradient can be compared to that determined directly from snow pit measurements at TKGTP5 and DGTP1 at $1000 \mathrm{~m}$ a.s.l. on the Taku Glacier (Pelto, 2011). On the date that each snow pit is excavated, the difference between measured w.e. at each snow pit and the TSL elevation on that date provides a direct surface 
Table 2. Accumulation measurements on longitudinal probing transect from 990 to $1100 \mathrm{~m}$ a.s.l. above the TSL on Taku Glacier in July 1998, 2004, 2005 and 2010.

\begin{tabular}{|c|c|c|c|c|c|c|c|}
\hline Pt. Name & Easting & Northing & $\begin{array}{r}\text { Elevation } \\
\text { (m a.s.l.) }\end{array}$ & $\begin{array}{c}1998 \\
\text { (mm w.e.) }\end{array}$ & $\begin{array}{r}2004 \\
\text { (mm w.e.) }\end{array}$ & $\begin{array}{r}2005 \\
\text { (mm w.e.) }\end{array}$ & $\begin{array}{r}2010 \\
\text { (mm w.e.) }\end{array}$ \\
\hline P1 & 541911 & 6501411 & 1099 & 910 & 1001 & 1030 & \\
\hline $\mathrm{P} 2$ & 542013 & 6501311 & 1097 & & 938 & 980 & \\
\hline P3 & 542115 & 6501200 & 1094 & 850 & 954 & 960 & \\
\hline P4 & 542217 & 6501111 & 1092 & & 925 & 1221 & \\
\hline P5 & 542319 & 6501000 & 1090 & 770 & 893 & 1177 & \\
\hline P6 & 542454 & 6500911 & 1089 & 800 & 882 & 1148 & \\
\hline P7 & 542568 & 6500800 & 1087 & & 873 & 960 & \\
\hline P8 & 542669 & 6500712 & 1085 & 850 & 859 & 962 & \\
\hline P9 & 542783 & 6500601 & 1084 & & 815 & 1075 & \\
\hline P10 & 542885 & 6500501 & 1082 & 910 & 871 & 1112 & \\
\hline P11 & 542998 & 6500412 & 1081 & & 916 & 1110 & \\
\hline $\mathrm{P} 12$ & 543100 & 6500312 & 1078 & & 936 & 1030 & 1370 \\
\hline P13 & 543202 & 6500201 & 1077 & 880 & 889 & 1143 & 1434 \\
\hline P14 & 543304 & 6500101 & 1074 & & 902 & 1156 & 1419 \\
\hline P15 & 543395 & 6500012 & 1073 & & 992 & 1171 & 1435 \\
\hline P16 & 543519 & 6499901 & 1070 & 770 & 1001 & 1218 & 1443 \\
\hline P17 & 543599 & 6499801 & 1068 & & 1035 & 1302 & 1413 \\
\hline P18 & 543712 & 6499701 & 1066 & 750 & 1004 & 1307 & 1385 \\
\hline P19 & 543814 & 6499612 & 1063 & & 963 & 1312 & 1316 \\
\hline P20 & 543905 & 6499512 & 1060 & & 981 & 1318 & 1327 \\
\hline P21 & 543996 & 6499412 & 1057 & 850 & 959 & 1344 & 1365 \\
\hline P22 & 544086 & 6499312 & 1056 & & 945 & 1278 & 1396 \\
\hline P23 & 544189 & 6499201 & 1052 & & 983 & 1278 & 1383 \\
\hline P24 & 544291 & 6499113 & 1050 & 830 & 950 & 1259 & 1350 \\
\hline P25 & 544393 & 6499001 & 1047 & & 927 & 1164 & 1350 \\
\hline P26 & 544495 & 6498901 & 1044 & 830 & 920 & 1161 & 1303 \\
\hline P27 & 544574 & 6498813 & 1042 & & 866 & 1116 & 1238 \\
\hline P28 & 544688 & 6498713 & 1039 & & 844 & 1142 & 1295 \\
\hline P29 & 544790 & 6498602 & 1036 & 740 & 814 & 1078 & 1226 \\
\hline P30 & 544903 & 6498513 & 1033 & & 796 & 1092 & 1202 \\
\hline P31 & 544994 & 6498391 & 1031 & & 774 & 1016 & 1225 \\
\hline P32 & 545074 & 6498302 & 1030 & 740 & 734 & 1052 & 1208 \\
\hline P33 & 545187 & 6498202 & 1027 & & 707 & 1041 & 1213 \\
\hline P34 & 545289 & 6498102 & 1025 & 660 & 689 & 1022 & 1180 \\
\hline P35 & 545380 & 6498002 & 1022 & & 684 & 968 & 1154 \\
\hline P36 & 545482 & 6497891 & 1021 & 660 & 697 & 963 & 1120 \\
\hline P37 & 545562 & 6497791 & 1019 & & 666 & 975 & 1141 \\
\hline P38 & 545642 & 6497713 & 1016 & 610 & 670 & 957 & 1118 \\
\hline P39 & 545733 & 6497613 & 1013 & & 639 & 941 & 1073 \\
\hline P40 & 545846 & 6497513 & 1010 & 550 & 661 & 922 & 1071 \\
\hline P41 & 545948 & 6497425 & 1006 & & 668 & 938 & 1090 \\
\hline P42 & 546039 & 6497313 & 1003 & 560 & 621 & 901 & 1109 \\
\hline P43 & 546130 & 6497213 & 1000 & & 659 & 889 & 1090 \\
\hline P44 & 546232 & 6497102 & 996 & 490 & 639 & 858 & 1099 \\
\hline P45 & 546323 & 6497025 & 994 & & 605 & 879 & 1079 \\
\hline P46 & 546414 & 6496914 & 992 & 550 & 565 & 834 & 1040 \\
\hline P47 & 546516 & 6496803 & 989 & & 617 & 843 & 1025 \\
\hline P48 & 546607 & 6496714 & 988 & 440 & 590 & 841 & 1066 \\
\hline P49 & 546698 & 6496603 & 985 & & 617 & 815 & 1070 \\
\hline P50 & 546800 & 6496503 & 981 & 410 & 646 & 726 & 1135 \\
\hline P51 & 546891 & 6496403 & 977 & & 576 & 789 & 1096 \\
\hline P52 & 547005 & 6496314 & 972 & 380 & 574 & 675 & 1135 \\
\hline P53 & 547107 & 6496214 & 967 & & 601 & 725 & 1116 \\
\hline P54 & 547198 & 6496114 & 963 & & 583 & 688 & 1116 \\
\hline P55 & 547300 & 6496003 & 960 & 360 & 587 & 694 & 1077 \\
\hline P56 & 547391 & 6495903 & 956 & & 405 & 680 & 1025 \\
\hline P57 & 547494 & 6495792 & 953 & 310 & 330 & 606 & 1036 \\
\hline P58 & 547596 & 6495715 & 949 & & & 780 & 1034 \\
\hline P59 & 547709 & 6495604 & 944 & & & 757 & 945 \\
\hline P60 & 547789 & 6495504 & 940 & & & 680 & 913 \\
\hline P61 & 547914 & 6495393 & 935 & & & 744 & 905 \\
\hline P62 & 547994 & 6495304 & 930 & & & 606 & 911 \\
\hline
\end{tabular}




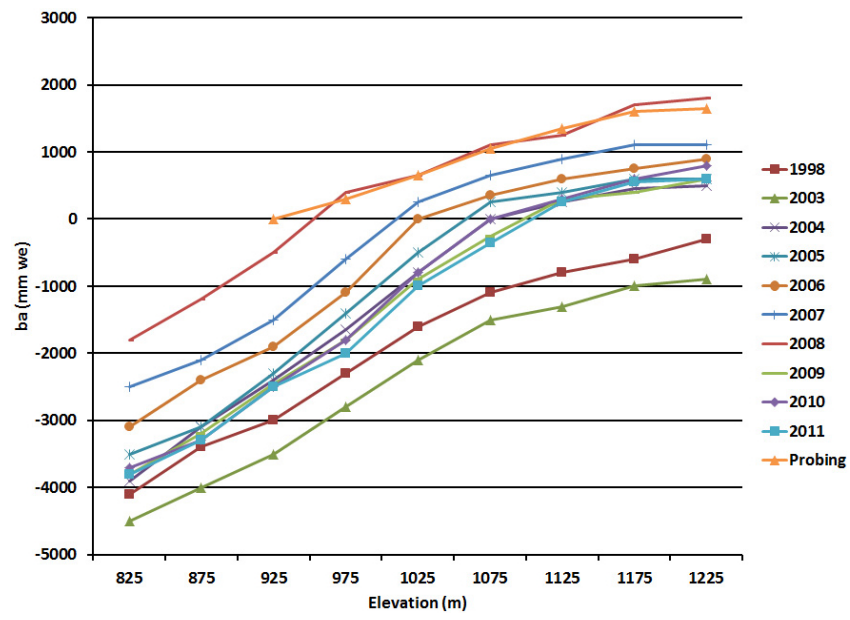

Figure 6. Annual surface mass balance profile on Lemon Creek Glacier for 1998 and 2003-2011, and probing gradient from 1998.

mass balance gradient measurement. The mass balance gradient derived from the snow pits was $2.6-3.5 \mathrm{~mm} \mathrm{~m}^{-1}$. This is less than that for probing, but the TSL on the date of snow pit excavation is almost always lower than the lowest elevation of the probing transects and represents a lower elevation band of 800 to $1000 \mathrm{~m}$ a.s.l.

On Lemon Creek Glacier the mass balance gradient generated annually from the ELA and snow pit elevations illustrates the similarity of the mass balance gradient from year to year. The mass balance gradient parallels the probed gradient in 1998 and has a range of 4.6 to $5.1 \mathrm{~mm} \mathrm{~m}^{-1}$ (Fig. 6).

\section{Balance gradient from TSL variation}

The TSL is readily identifiable on 34 Landsat scenes acquired from 1995 to 2011, and was delineated using the software package US Geological Survey Globalization Viewer. The Juneau Icefield falls in path/row 58/19 and 57/19; all images are false color RGB composites, bands 3,4 , and 5 , with a $2 \%$ linear stretch applied. Selected scenes are cloud free at the TSL and because of low surrounding mountain slopes shadows are not an issue. The spatial resolution of $30 \mathrm{~m}$, combined with mean surface gradients of $0.04-0.08 \mathrm{~m} \mathrm{~m}^{-1}$, yields an error of less than $\pm 5 \mathrm{~m}$ in TSL elevation. The exception is when the TSL rises to $1200 \mathrm{~m}$ a.s.l. or is below $900 \mathrm{~m}$ a.s.l. on Lemon Creek Glacier; in both cases the surface slopes increases, leading to higher error margins. The satellite images were georeferenced in ArcMap 9.3 using five topographically unique reference points. The data frame containing imagery and base map was transformed to NAD_1983_UTM_Zone_8N to ensure spatial accuracy for measurements (Mernild et al., 2013). For years with multiple images, the rate of rise of the TSL is determined. This rate of rise is only calculated for periods of longer than 15 days. The 15 day or greater time period is chosen because errors in TSL elevation assessment are constant regardless of time

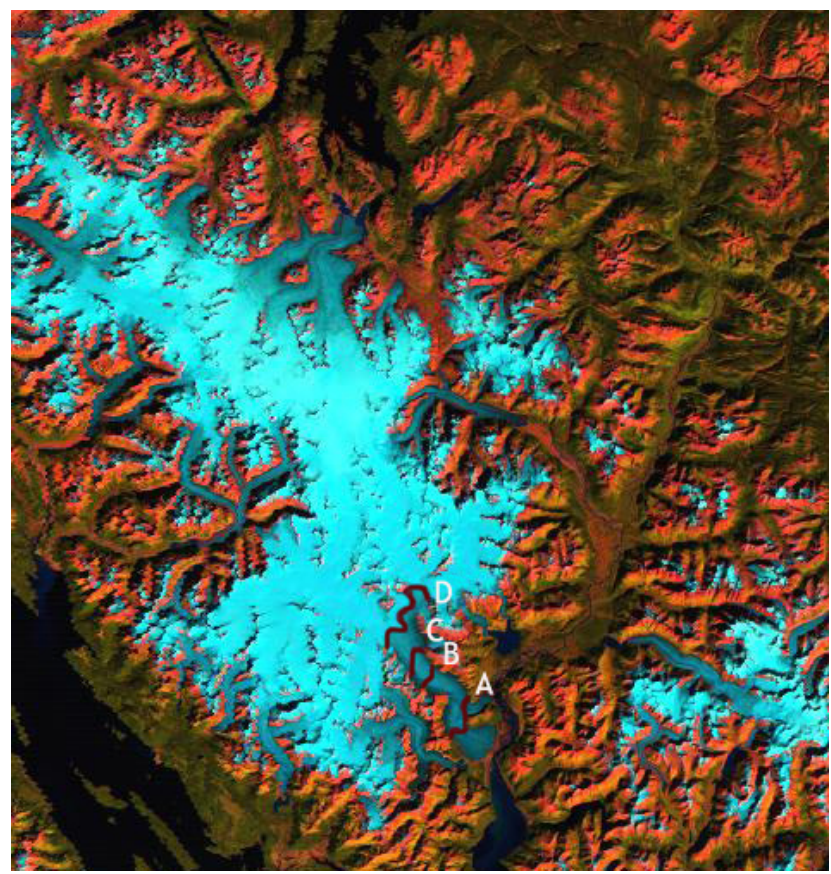

Figure 7. TSL identification on Taku Glacier in 2006 Landsat image from 9/14/2006. $A=5 / 26 / 2006, B=7 / 5 / 2006, C=7 / 28 / 2006$, $\mathrm{D}=9 / 14 / 2006$

period length; hence longer time periods reduce the error in calculation of the rate of rise.

For example, in 2006 the TSL was identified in five Landsat images on Taku Glacier. The TSL in 2006 rose from $370 \mathrm{~m}$ a.s.l. on 26 May to $575 \mathrm{~m}$ a.s.l. on 10 June, $730 \mathrm{~m}$ a.s.l. on 5 July, $760 \mathrm{~m}$ a.s.l. on $29 \mathrm{July}$, and finally $975 \mathrm{~m}$ a.s.l. on 15 September (Fig. 7; Table 3). The TSL rise ranged from 3.1 to $6.2 \mathrm{~m} \mathrm{~d}^{-1}$. Mean rise of the TSL for 15 periods averages $4.1 \pm 0.9 \mathrm{~m} \mathrm{~d}^{-1}$ during the July-September period, for the elevation range between 750-1100 m a.s.l. (Table 3; Fig. 7).

The TSL for Lemon Creek Glacier was observed for 34 dates from 1998-2011; these observations define 18 time periods for which satellite observations were at least 15 days apart (Table 3; Fig. 8). For Lemon Creek Glacier the observed positive TSL migration rates varied from 3.0 to $5.2 \mathrm{~m} \mathrm{~d}^{-1}$, with a mean of $4.0 \pm 0.6 \mathrm{~m} \mathrm{~d}^{-1}$. The mean TSL migration rate on Lemon Creek Glacier of $3.8 \mathrm{~m} \mathrm{~d}^{-1}$ compares well with the mean migration rate of $3.7 \mathrm{~m} \mathrm{~d}^{-1}$ on nearby Taku Glacier (Pelto, 2011). This suggests a consistency in the rate of rise of the TSL from glacier to glacier and year to year on the Juneau Icefield.

\section{ELA-TSL observations}

Observations of the TSL and ELA can now be reliably made each year using a combination of less frequent Landsat Imagery and the daily MODIS images (Rabatel et al., 2005; Hock et al., 2007; Pelto, 2011). Use of the latter ensures 
Table 3. Transient snow line observation on Lemon Creek Glacier (LCG) and Taku Glacier (TG), and the respective rates of rise between image dates at least 16 days apart. The date listed is the final date of the measurement interval. Rate of rise is not calculated for Taku Glacier if the TSL is below $800 \mathrm{~m}$ a.s.l.

\begin{tabular}{|c|c|c|c|c|}
\hline $\begin{array}{l}\text { Date } \\
(\mathrm{mm} / \mathrm{dd} / \mathrm{yyyy})\end{array}$ & $\begin{array}{c}\text { LC TSL } \\
\text { (m a.s.l.) }\end{array}$ & $\begin{array}{l}\text { Lemon Creek } \\
\text { TSL rate of } \\
\text { rise }\left(\mathrm{m} \mathrm{d}^{-1}\right)\end{array}$ & $\begin{array}{r}\text { Taku TSL } \\
\text { (m a.s.1.) }\end{array}$ & $\begin{array}{l}\text { Taku TSL } \\
\text { rate of } \\
\text { rise }\left(\mathrm{m} \mathrm{d}^{-1}\right)\end{array}$ \\
\hline $7 / 11 / 1998$ & 950 & & 850 & \\
\hline $7 / 30 / 1998$ & 1025 & 3.95 & 880 & \\
\hline $8 / 20 / 1998$ & 1100 & 3.57 & 980 & 4.76 \\
\hline $9 / 16 / 1998$ & 1200 & 3.85 & 1075 & 4.42 \\
\hline 8/31/1999 & 950 & & 850 & \\
\hline $8 / 29 / 2000$ & 900 & & 775 & \\
\hline $8 / 15 / 2001$ & 900 & & 800 & \\
\hline $10 / 3 / 2002$ & 1025 & & 950 & \\
\hline $7 / 12 / 2003$ & 1040 & & 915 & \\
\hline $8 / 5 / 2003$ & 1110 & 3.33 & 950 & \\
\hline $8 / 22 / 2003$ & 1170 & 3.53 & 1075 & 3.90 \\
\hline $7 / 15 / 2004$ & 950 & & 850 & \\
\hline $8 / 8 / 2004$ & 1075 & 5.21 & 930 & 3.48 \\
\hline $8 / 16 / 2004$ & 1100 & 4.69 & 950 & 3.13 \\
\hline $8 / 24 / 2004$ & 1150 & 4.69 & 980 & 3.13 \\
\hline $9 / 1 / 2004$ & 1100 & 3.13 & 1050 & 6.25 \\
\hline $8 / 10 / 2005$ & 1050 & & 920 & \\
\hline $9 / 11 / 2005$ & 1050 & & 1000 & 4.06 \\
\hline $7 / 29 / 2006$ & 935 & & 760 & \\
\hline $9 / 15 / 2006$ & 1025 & 3.04 & 975 & 4.48 \\
\hline $8 / 8 / 2007$ & 875 & & 850 & \\
\hline $8 / 16 / 2007$ & 925 & & 900 & \\
\hline $9 / 2 / 2007$ & 1000 & 4.41 & 965 & 3.82 \\
\hline $7 / 2 / 2008$ & 800 & & 400 & \\
\hline $8 / 19 / 2008$ & 900 & 3.38 & 775 & \\
\hline $7 / 13 / 2009$ & 900 & & 750 & \\
\hline $8 / 5 / 2009$ & 975 & 3.57 & 825 & 3.26 \\
\hline $8 / 29 / 2009$ & 1050 & 3.13 & 900 & 3.13 \\
\hline $9 / 14 / 2009$ & 1050 & & 950 & 3.13 \\
\hline $7 / 8 / 2010$ & 925 & & 580 & \\
\hline $8 / 3 / 2010$ & 1000 & 3.85 & 775 & \\
\hline $8 / 14 / 2010$ & 1050 & 3.57 & 800 & \\
\hline $8 / 28 / 2010$ & 1075 & 3.26 & 900 & 5.00 \\
\hline
\end{tabular}

having an observation within a short period of the end of the ablation season. The last usable Landsat image for the ablation season is used to assess the TSL for six glaciers of the Juneau Icefield from 1995 to 2011: Eagle, Herbert, Lemon Creek, Mendenhall, Norris and Taku (Table 4; Fig. 9). The observed TSL between glaciers is highly correlated for all glaciers with $R^{2}$ exceeding 0.82 in all cases. This paper presents only a single late season TSL from each year; additional analysis is required to determine the rate of change of TSL in September for each glacier, which will allow a more precise determination of the ELA. The ELA can be reasonably estimated from the late season TSL observation on each glacier once both the rate of rise and the date of the end of the ablation season are known. The date of the end of the ablation season can be determined from climate records. The ELA in turn is a good indicator of $B_{\text {a }}$ (Rabatel et al., 2005). The World Glacier Monitoring Service derives plots of ELA ver-

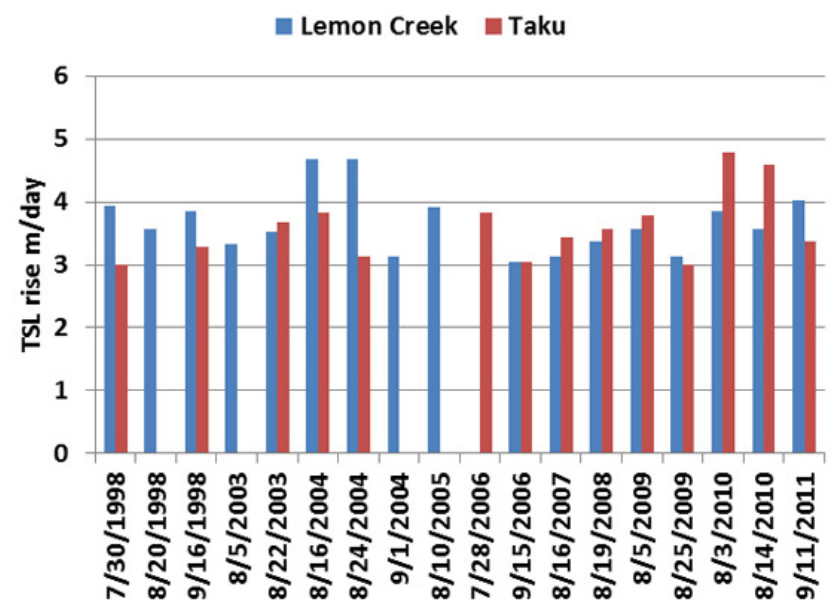

Figure 8. TSL elevation rise rate on Taku Glacier and Lemon Creek Glacier for selected periods of at least 15 days where the TSL could be identified using Landsat imagery. The date given is the end of the period. Table 3 contains the raw data.

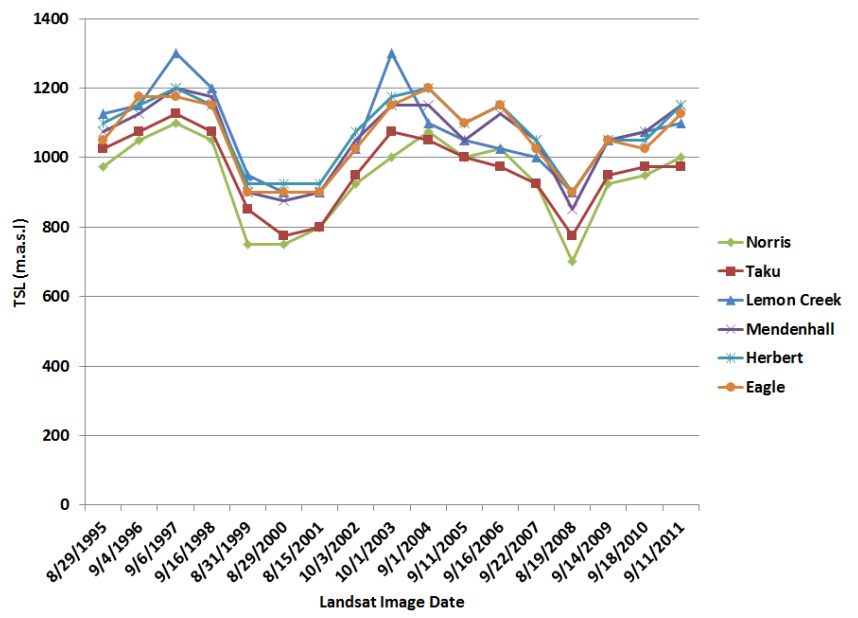

Figure 9. Transient snow line elevation on the same date on six Juneau Icefield glaciers, 1995-2011.

sus $B_{\mathrm{a}}$ each year for each glacier. The plots generated for the WGMS (2011) from Lemon Creek Glacier are below. The fit is not good for Taku Glacier, $R^{2}=0.66$ (Fig. 10). The fit for Lemon Creek Glacier is excellent for the ELA- $B_{\mathrm{a}}, R^{2}=0.87$ (Fig. 11).

\section{Conclusions}

The annual surface mass balance record from Lemon Creek Glacier and Taku Glacier illustrates a decline in $B_{\mathrm{a}}$ mass balance for both glaciers after 1985. Independent geodetic observations of glacier mass balance validate the longterm changes quantified by the $B_{\mathrm{a}}$ for both glaciers. Going forward it is important to utilize both ground penetrating radar and satellite imagery to better quantify variations in 
Table 4. TSL observation (m a.s.1.) on the same date from Landsat Images on six Juneau Icefield glaciers.

\begin{tabular}{lrrrrrr}
\hline Date (mm/dd/yyyy) & Norris & Taku & Lemon Creek & Mendenhall & Herbert & Eagle \\
\hline $8 / 29 / 1995$ & 975 & 1025 & 1125 & 1075 & 1100 & 1050 \\
$9 / 4 / 1996$ & 1050 & 1075 & 1150 & 1125 & 1150 & 1175 \\
$9 / 6 / 1997$ & 1100 & 1125 & 1300 & 1200 & 1200 & 1175 \\
$9 / 16 / 1998$ & 1050 & 1075 & 1200 & 1175 & 1150 & 1150 \\
$8 / 31 / 1999$ & 750 & 850 & 950 & 900 & 925 & 900 \\
$8 / 29 / 2000$ & 750 & 775 & 900 & 875 & 925 & 900 \\
$8 / 15 / 2001$ & 800 & 800 & 900 & 900 & 925 & 900 \\
$10 / 3 / 2002$ & 925 & 950 & 1025 & 1050 & 1075 & 1025 \\
$10 / 1 / 2003$ & 1000 & 1075 & 1300 & 1150 & 1175 & 1150 \\
$9 / 1 / 2004$ & 1075 & 1050 & 1100 & 1150 & 1200 & 1200 \\
$9 / 11 / 2005$ & 1000 & 1000 & 1050 & 1050 & 1100 & 1100 \\
$9 / 16 / 2006$ & 1025 & 975 & 1025 & 1125 & 1150 & 1150 \\
$9 / 22 / 2007$ & 925 & 925 & 1000 & 1050 & 1050 & 1025 \\
$8 / 19 / 2008$ & 700 & 775 & 900 & 850 & 900 & 900 \\
$9 / 14 / 2009$ & 925 & 950 & 1050 & 1050 & 1050 & 1050 \\
$9 / 18 / 2010$ & 950 & 975 & 1075 & 1075 & 1050 & 1025 \\
$9 / 11 / 2011$ & 1000 & 975 & 1100 & 1150 & 1150 & 1125 \\
\hline
\end{tabular}

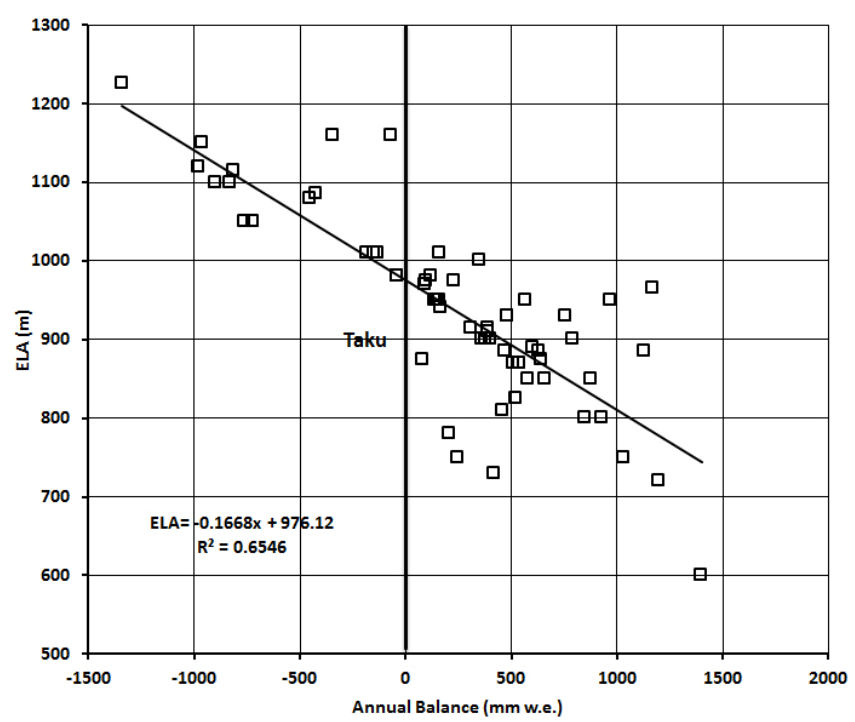

Figure 10. Relationship of Taku Glacier annual surface mass balance and the ELA.

accumulation and ablation across the glacier. The mass balance records also warrant the detailed investigation that has been undertaken on Wolverine Glacier and Gulkana Glacier to better evaluate potential error.

The mass balance profile and gradient of the Taku Glacier and Lemon Creek Glacier is consistent in the region near the ELA from year to year. The rate of rise of the TSL is relatively consistent from year to year and glacier to glacier on the Juneau Icefield. The ELA provides a reasonable first estimate of $B_{\mathrm{a}}$ on Taku Glacier and Lemon Creek Glacier, and, as such, determination of this relationship for other Juneau Icefield glaciers utilizing simultaneous TSL variations with

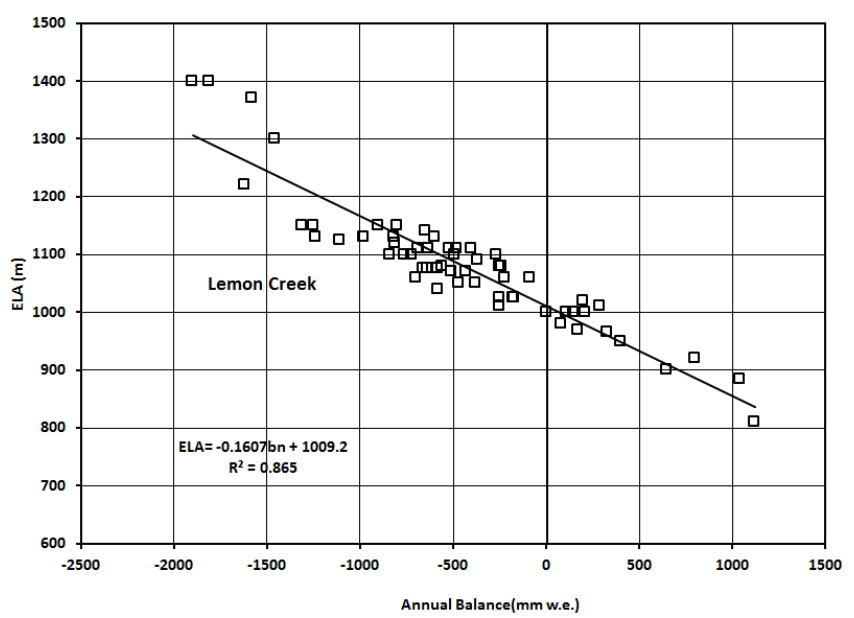

Figure 11. Relationship of Lemon Creek Glacier annual surface mass balance and the ELA.

Lemon Creek and Taku Glacier has value. Taku Glacier has a large surface area in the vicinity of the ELA, which makes the glacier sensitive to small changes in the ELA and small changes in the balance profile near the ELA. Both would reduce the correlation between ELA and $B_{\mathrm{a}}$. Continued use of direct field observations of the mass balance gradient and TSL variation should help better identify not only the ELA, but aid in adjusting the annual mass balance gradient in this critical interval (Mernild et al., 2013).

Acknowledgements. This data set could not have been developed without the long term efforts of Maynard Miller, Scott McGee, Toby Dittrich and Matt Beedle. JIRP has recieved critical long term support from NSF and NASA. 
Edited by: D. Carlson

\section{References}

Arendt, A. A.: Volume changes of Alaska glaciers: contributions to rising sea level and links to climate change, Ph.D. dissertation, University of Alaska, Fairbanks, 2006.

Arendt, A. A., Echelmeyer, K. A., Harrison, W. D., Lingle, C. S., and Valentine, V. B.: Rapid wastage of Alaska glaciers and their contribution to rising sea level, Science, 297, 382-386, 2002.

Boyce, E., Motyka, R., and Truffer, M.: Flotation and retreat of a lake-calving terminus, Mendenhall Glacier, southeast Alaska, USA, J. Glaciol., 53, 211-224, 2007.

Cogley, J. G., Hock, R., Rasmussen, L. A., Arendt, A. A., Bauder, A., Braithwaite, R. J., Jansson, P., Kaser, G., Möller, M., Nicholson, L., and Zemp, M.: Glossary of glacier mass balance and related terms, UNESCO - International Hydrological Programme, IACS, IHP-VII Technical Documents in Hydrology, No. 86, 2011.

Criscitiello, A., Kelly, M., and Tremblay, B.: The Response of Taku and Lemon Creek Glaciers to Climate, Arct. Antarct. Alp. Res., 42, 34-44, 2010.

Heusser, C. E. and Marcus, M. G.: Surface movement, hydrological change and equilibrium flow on Lemon Creek Glacier, Alaska, J. Glaciol., 5, 61-75, 1964.

Hock, R., Koostra, D., and Reijmeer, C.: Deriving glacier mass balance from accumulation area ratio on Storglaciären, Sweden, in: Glacier Mass Balance Changes and Meltwater Discharge IAHS, 318, 163-170, 2007.

LaChapelle, E. R.: Snow studies on the Juneau Icefield, in: Variability of glacier mass, edited by: Walters, R. A. and Meier, M. F., American Geographical Society, JIRP Report no. 9, 1589, 1954.

Larsen, C. F., Motyka, R. J., Arendt, A. A., Echelmeyer, K. A., and Geissler, P. E.: Glacier changes in southeast Alaska and northwest British Columbia and contribution to sea level rise, J. Geophys. Res., 112, F01007, doi:10.1029/2006JF000586, 2007.

March, R. S. and Trabant, D. C.: Mass balance, meteorological, ice motion, surface altitude, and runoff data at Gulkana Glacier, Alaska, 1992 balance year: U.S. Geological Survey Water-Resources Investigations Report 95-4277, 1996.

Marcus, M. G., Chambers, F. B., Miller, M. M., and Lang, M.: Recent trends in The Lemon Creek Glacier, Alaska, Phys. Geogr., 16, 150-161, 1995.

Mayo, L. R., Trabant, D. C., and March, R. S.: A 30-Year Record of Surface Mass Balance (1966-95), and Motion and Surface Altitude (1975-95) at Wolverine Glacier, Alaska: U.S. Geological Survey Open-File Report 2004-1069, 2004.
Mernild, S., Pelto, M., Malmros, J., Yde, J., Knudsen, N., and Hanna, E.: Identification of snow ablation rate, ELA, $\mathrm{AAR}$ and net mass balance using transient snowline variations on two Arctic glaciers, J. Glaciol., 59, 649-659, doi:10.3189/2013JoG12J221, 2013.

Miller, M. M.: A principles study of factors affecting the hydrological balance of the Lemon Creek Glacier system and adjacent sectors of the Juneau Icefield, SE Alaska, 1965-1969, Institute of Water Research, Michigan State University and the U.S. Federal Office of Water Resources Research, Department of Interior, Publication No. 33, 1-295, 1972.

Miller, M. M. and Pelto, M. S.: Mass Balance measurements on the Lemon Creek Glacier, Juneau Icefield, AK 1953-1998, Geogr. Ann., 81A, 671-681, 1999.

Motyka, R. J. and Echelmeyer, K. A.: Taku Glacier (Alaska, U.S.A.) on the move again: active deformation of proglacial sediments, J. Glaciol., 49, 50-59, 2003.

Nolan, M., Motyka, R., Echelmeyer, K., and Trabant, D.: Ice thickness Measurements of Taku Glacier, Alaska, USA, and their Relevance to it Recent Behavior, J. Glaciol., 41, 541-552, 1995.

Pelto, M.: Utility of late summer transient snowline migration rate on Taku Glacier, Alaska, The Cryosphere, 5, 1127-1133, doi:10.5194/tc-5-1127-2011, 2011.

Pelto, M. and Miller, M. M.: Mass Balance of the Taku Glacier, Alaska from 1946 to 1986, Northwest Sci., 64, 121-130, 1990.

Pelto, M. S., Miller, M. M., Adema, G. W., Beedle, M. J., McGee, S. R., Sprenke, K. F., and Lang, M.: The equilibrium flow and mass balance of the Taku Glacier, Alaska 1950-2006, The Cryosphere, 2, 147-157, doi:10.5194/tc-2-147-2008, 2008.

Post, A. and Motyka, R.: Taku and Le Conte Glaciers, Alaska: Calving speed control of late-Holocene asynchrounous advances and retreats, Phys. Geogr., 16, 59-82, 1995.

Rabatel, A., Dedieu, J., and Vincent, C.: Using remote-sensing data to determine equilibrium line altitude and mass balance time series: validation on three French glaciers, 1994-2002, J. Glaciol., 51, 539-546, 2005.

Ramage, J. M., Isacks, B. L., and Miller, M. M.: Radar Glacier zones in southeast Alaska, U.S.A.: field and satellite observations, J. Glaciol., 46, 287-296, 2000.

Sapiano, J. J., Harrison, W. D., and Echelmeyer, K. A.: Elevation, volume and terminus changes of nine glaciers in North America, J. Glaciol., 44, 119-135, 1998.

Van Beusekom, A. E., O’Neel, S. R., March, R. S., Sass, L. C., and Cox, L. H.: Re-analysis of Alaskan benchmark glacier mass balance data using the index method: U.S. Geological Survey Scientific Investigations Report 2010-5247, 2010.

Zemp, M., Hoelzle, M., and Haeberli, M.: Six decades of glacier mass balance observations: a review of the worldwide monitoring network, Ann. Glaciol., 50, 101-111, 2009. 